\title{
Experimental Investigation on Strength and Water Permeability of Mortar Incorporate with Rice Straw Ash
}

\author{
Surajit Munshi and Richi Prasad Sharma \\ Department of Civil Engineering, NIT Agartala, Tripura 799046, India \\ Correspondence should be addressed to Surajit Munshi; surajitm964@gmail.com
}

Received 22 July 2016; Revised 31 August 2016; Accepted 8 September 2016

Academic Editor: Charles C. Sorrell

Copyright (C) 2016 S. Munshi and R. P. Sharma. This is an open access article distributed under the Creative Commons Attribution License, which permits unrestricted use, distribution, and reproduction in any medium, provided the original work is properly cited.

\begin{abstract}
The utilization of various agricultural residue ash as a pozzolanic material has the potential to reduce both the environmental impact and cost associated with building materials. In this paper, the authors studied the strength and permeability of mortar using different percentages of rice straw ash (RSA) as cement replacement and the possibilities of using RSA as a pozzolanic material. Locally available rice straws were burnt at a temperature of $600^{\circ} \mathrm{C}$ and ground to make RSA. The chemical and physical properties of RSA were studied and the outcome shows that the ash contains about $76 \%$ of silica in it. This investigation further focused the strength and water permeability of mortar using RSA, which demonstrates that up to $10 \%$ replacement both the strength and permeability have a better result than that of control specimen.
\end{abstract}

\section{Introduction}

The incorporation of mineral admixtures in building materials can produce benefits like improvements in the mechanical properties and durability [1]. For several decades, the use of rice husk ash as a highly reactive pozzolanic material in building materials production has been researched [2, 3]. The use of rice husk ash (RHA) as a supplementary cementing material in construction is of great interest to many developing countries where Portland cement is in short supply but rice production is in abundance $[4,5]$. A highly reactive pozzolan is obtained when RHA is burnt under controlled conditions $[6,7]$. The use of agrowaste ashes as cement replacement can produce building materials of standard quality and also improve the durability. Several researchers have studied the pozzolanic properties using different agricultural residue ashes [8-15]. Worldwide many researchers work with rice husk ash and get satisfactory results of which most of them found that the main composition of rice husk ash is silica (about 80\%-95\%) [16-21]. But the pozzolanic properties of rice straw ash have been examined only by a few researchers [22].

Rice straw is the stem of rice plants, which is removed during the harvesting of rice and it is considered as an agriculture waste material. Agriculture constitutes one of the main sectors of the economy of India. India is the second largest rice producing country after China in the world and produces about 155.682 million metric tons of rice. Each ton of rice produces an equal amount of straw as a byproduct. Rice husk attains silica during its growth and it transmit though its straw. During this process most of the silica retains in its cellular structure in which when burnt properly the amorphous silica remains in the form of ash. It has been investigated that the main constituent of rice straw ash is also silica, which acquires about $62 \%$ to $82 \%$ of silica [23-25].

The aim of this research is to study the strength and water permeability of mortar containing ground rice straw ash prepared by burning at a controlled temperature of $600^{\circ} \mathrm{C}$. As mortar is one of the most used building materials the consequent technical and economic advantages can be very significant. However, results on the water permeability of mortar containing rice straw ash have been rarely reported. Different percentages of replacement levels were studied and the results were compared to normal specimen made of ordinary Portland cement only. The knowledge on the strength and permeability of mortar incorporate with rice straw ash is of interest and could be beneficial for the understanding of 
TABLE 1: Physical properties of OPC and RSA.

\begin{tabular}{lcc}
\hline Properties & Cement $(\mathrm{OPC})$ & Rice straw ash (RSA) \\
\hline Specific gravity & 3.14 & 2.1 \\
Surface area $\left(\mathrm{m}^{2} / \mathrm{g}\right)$ & 308 & 365 \\
\hline
\end{tabular}

TABLE 2: Chemical properties of OPC and RSA.

\begin{tabular}{lcc}
\hline Chemical compositions & Cement (OPC) & Rice straw ash (RSA) \\
\hline $\mathrm{SiO}_{2}$ & 21.5 & 76.00 \\
$\mathrm{Al}_{2} \mathrm{O}_{3}$ & 5.2 & 0.69 \\
$\mathrm{Fe}_{2} \mathrm{O}_{3}$ & 3.5 & 0.63 \\
$\mathrm{CaO}$ & 65.4 & 4.96 \\
$\mathrm{MgO}$ & 1.2 & 2.65 \\
$\mathrm{SO}_{3}$ & 2.7 & 1.90 \\
$\mathrm{Na}_{2} \mathrm{O}$ & 0.2 & 1.36 \\
$\mathrm{~K}_{2} \mathrm{O}$ & 0.2 & 9.89 \\
\hline
\end{tabular}

the mechanism as well as for future application of rice straw ash in enhancing performance of the mortar.

\section{Experimental Program}

\subsection{Materials}

2.1.1. Cement and Incorporated Materials. Ordinary Portland cement (OPC) of 43 grades conforming to IS: 8112-2013 was used for all mortar mixtures. Rice straw ash collected was locally available from South Tripura district of Tripura, India, and was burnt at controlled temperature of $600^{\circ} \mathrm{C}$. After burning, they were ground until $95 \%$ of the particles passed through $90 \mu \mathrm{m}$ sieve. These materials were used partially to replace OPC to cast mortar specimen. Physical properties and chemical compositions of both cement and rice straw ash are shown in Tables 1 and 2.

2.1.2. Aggregates. Locally available sand was used throughout the experimental work so as to keep the fine aggregate variable constant. The sieve analysis results of the aggregate fit within the limits set out in IS: 383-1970 for grading zone IV. The fineness modulus of the fine aggregate is 2 with a specific gravity of 2.43 and silt and clay content is $2 \%$.

2.2. Mortar Mixtures. Cement was partially replaced by ground rice straw ash (RSA) at $5 \%, 10 \%$, and $15 \%$ by weight of binder. Table 3 shows the proportions of mixture of the materials by weight used for making cement mortar specimens incorporate with rice straw ash. One set of controlled specimen (OPC) is prepared individually for every test to make a comparison with RSA specimens. For every mix, minimum three samples were prepared. The result reported was the average of three samples tested.

\subsection{Testing}

2.3.1. Normal Consistency. Vicat apparatus (conforming IS 5513-1996) was used to measure the normal consistency of cement paste. The test was conducted using standard method

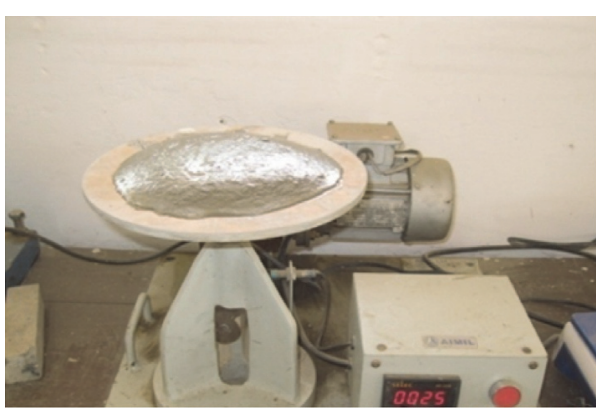

Figure 1: Flow test apparatus.

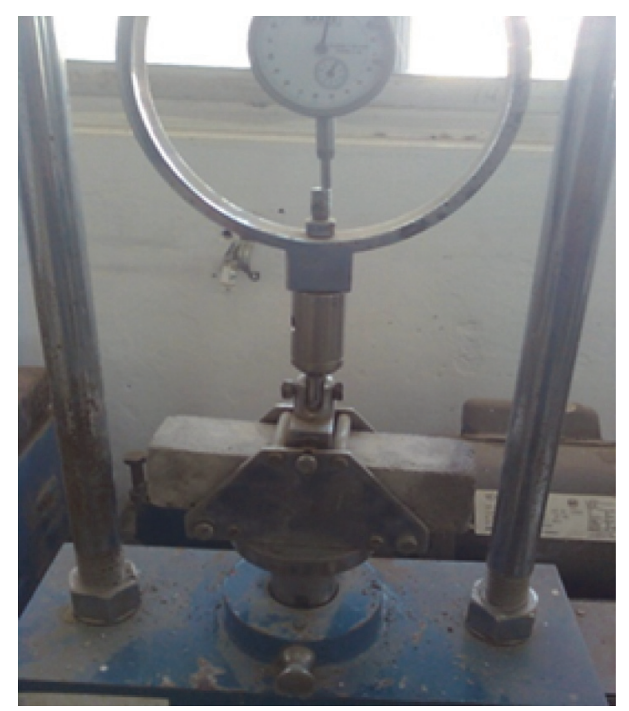

FIgURE 2: Flexural testing machine.

as per IS: 4031 (Part 4), 1988. Four types of mixtures were prepared with a replacement level of cement by $0 \%, 5 \%, 10 \%$, and $15 \%$ of RSA, respectively.

2.3.2. Workability Test. The workability of all the four mixtures was investigated throughout the research. To determine workability of mortar, flow table (conforming IS 5512-1983) test was performed. Figure 1 shows the flow test of mortar.

2.3.3. Flexural Strength. For this test, the specimens of mortar beam bars of size $40 \times 40 \times 160 \mathrm{~mm}$ are prepared. Curing of the specimens was done for 7 days, 14 days, and 28 days and then the samples were kept in the oven at $100^{\circ} \mathrm{C}$ for 24 hours. The mortar bars were taken out from the oven and these bars were cooled at room temperature. After that, required test was performed in accordance with ASTM C348-14. Figure 2 shows the flexural testing machine.

2.3.4. Compressive Strength. The compressive strength (CS) was performed by compressive testing machine as shown in Figure 3. It was tested in accordance with the ASTM C109 at the ages of 7, 14, and 28 days. Cubical specimens were casted and demolded 24 hours after casting and the specimens were stored in water at $23^{\circ} \mathrm{C}$ chamber for curing until the test ages. Here compressive strength was tested by compression testing 
TABLE 3: Mix proportion by weight used in making mortar specimens.

\begin{tabular}{lcccccc}
\hline Mix number & RSA (\%) & (Cement + RSA) : sand & Cement (grams) & $\begin{array}{c}\text { Sand } \\
\text { (grams) }\end{array}$ & $\begin{array}{c}\text { RSA } \\
\text { (grams) }\end{array}$ & $\begin{array}{c}\text { Number of } \\
\text { specimens }\end{array}$ \\
\hline 1 & 00 & $1: 3$ & 185.00 & 555 & 00 & 3 \\
2 & 05 & $1: 3$ & 175.75 & 555 & 9.25 \\
3 & 10 & $1: 3$ & 166.50 & 555 & 18.5 \\
4 & 15 & $1: 3$ & 157.25 & 555 & 27.75 \\
\hline
\end{tabular}

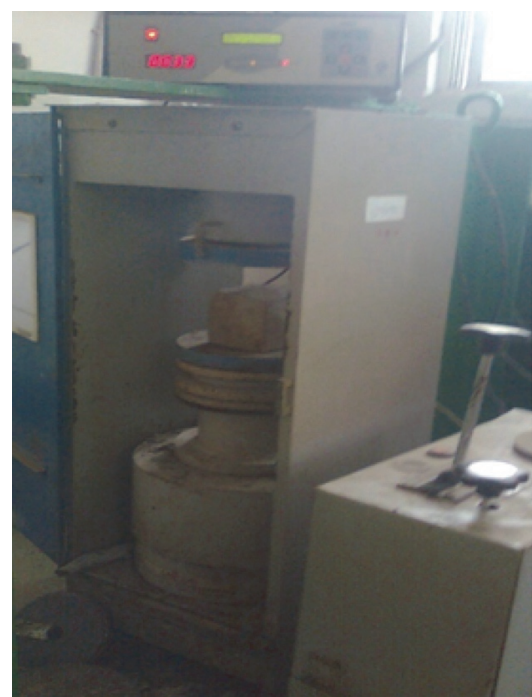

FIGURE 3: Compressive testing machine.

machine. For every mix sample, three cubical samples were prepared. The compressive strength reported was the average of three samples tested.

2.3.5. Water Permeability. The penetration method and steady flow method are available for the investigation of water permeability of mortar. The steady flow method was applied to test the permeability of mortar (as per ASTM C158513). The coefficient of water permeability was determined by measuring the amount of water passing through the specimen and calculated using Darcy's law and the equation of continuity. Cylinders $100 \mathrm{~mm}$ in diameter and $200 \mathrm{~mm}$ in height were used to determine the permeability $(K)$. Two days before testing the permeability, the samples were prepared by sawing of $40 \mathrm{~mm}$ thick slice from the middle of the cylinder. After drying in the laboratory for 24 hours, the slice was cast around with $25 \mathrm{~mm}$ thick nonshrinkage epoxy resin to prevent the water leakage. The epoxy resin was allowed to harden and dry for another 24 hours. The specimen was then installed in the lodging cell, and then the water pressure of $0.5 \mathrm{MPa}$ was applied. The time and the amount of water passed through the specimen were monitored until the constant flow rate was obtained.

\section{Results and Discussion}

3.1. Particular Size Analysis and Scanning Electron Microscope (SEM). Through analysis it was observed that the particle

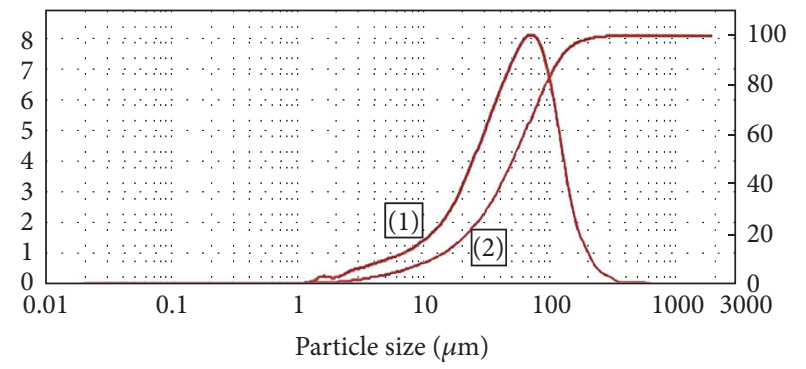

(1) Particular size distribution

(2) Cumulative size distribution

Figure 4: Particular size analysis of RSA.

size range varies from 1.44 to $120.22 \mu \mathrm{m}$. In the RSA sample, the size of the particles of about $90 \%$ is below $71.69 \mu \mathrm{m}$ and $10 \%$ of the particles contain $7.35 \mu \mathrm{m}$ size, whereas the size of about $50 \%$ of the sample particles is below $29.73 \mu \mathrm{m}$. The strength properties of mortar depend on the particular size of the materials. If the size of the particles is finer then the strength will also be more, as the finer particles fill the gaps and voids of the mortar. The particular size distribution of the RSA sample is shown in Figure 4.

Figure 5 shows the scanning electron micrographs of rice straw ash. It has been observed that size of most of the particles of this ash is in micro level but few particles are in nanometer. This figure indicates that the ash particles had irregular and porous surface which is convenient for a pozzolanic material.

3.2. X-Ray Diffraction. The mineralogical phases present in the powdered form of RSA sample were investigated by means of $\mathrm{X}$-ray diffraction with $\mathrm{Cu}-\mathrm{K} \alpha$ radiation in steps of $0.5^{\circ}(2 \theta)$ at a rate of $1^{\circ}(2 \theta)$ per minute. Figure 6 shows the $\mathrm{X}$ ray diffraction patterns of rice straw ash generated at $600^{\circ} \mathrm{C}$. It was monitored that quartz and potassium oxide are present as major constituent with the amount of silicate components and lesser amount of calcite. It has been observed that the quartz peak value is 3.34 and potassium oxide peak value is 3.02 and calcite peak value is 3.02 .

3.3. Normal Consistency. The percentage of cement replacement level by rice straw ash against standard consistency graph is shown in Figure 7. It was observed that the water demand for standard consistency linearly increases with an increase of cement replacement level by rice straw ash. The consistency results are shown in percentage. 


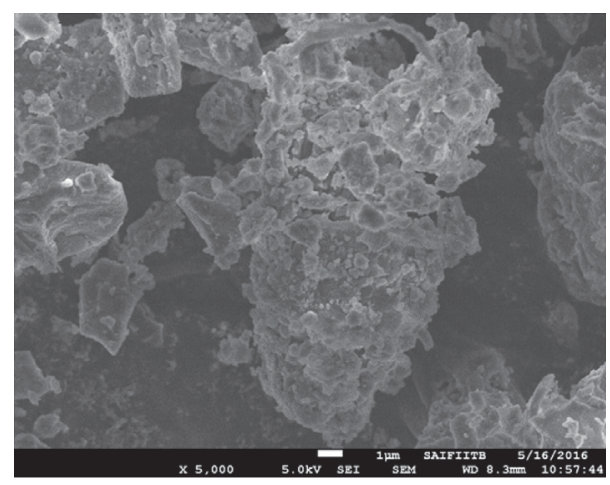

FIGURE 5: SEM micrograph of prepared rice straw ash.

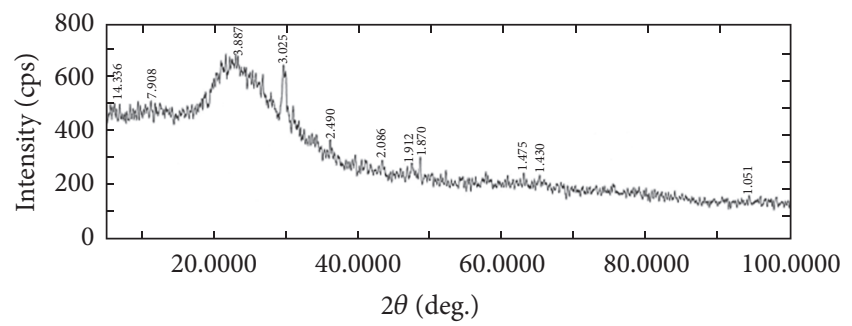

FIGURE 6: XRD pattern of RSA.

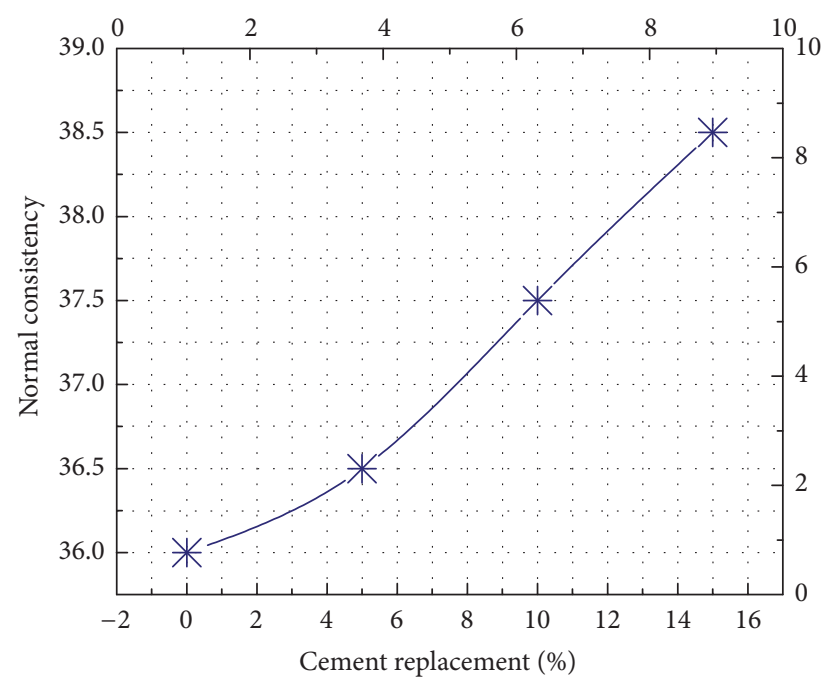

FIgURE 7: Normal consistency of cement with RSA.

3.4. Workability Test. Table 4 shows the workability result in $\mathrm{mm}$ with respect to water binder ratio (W/B). It has been observed that mix containing rice straw ash as a cement replacement increases the water requirement compared to that of control mortar. The W/B ratio also increased with an increase in the replacement level of cement by rice straw ash. The increase is due to the porous surface property of rice straw ash.

3.5. Compressive Strength. The variation of compressive strength (CS) of mortar made by replacement of cement with different percentage of rice straw ash at curing time of 7,14 , and 28 days is shown in Figure 8. The compressive

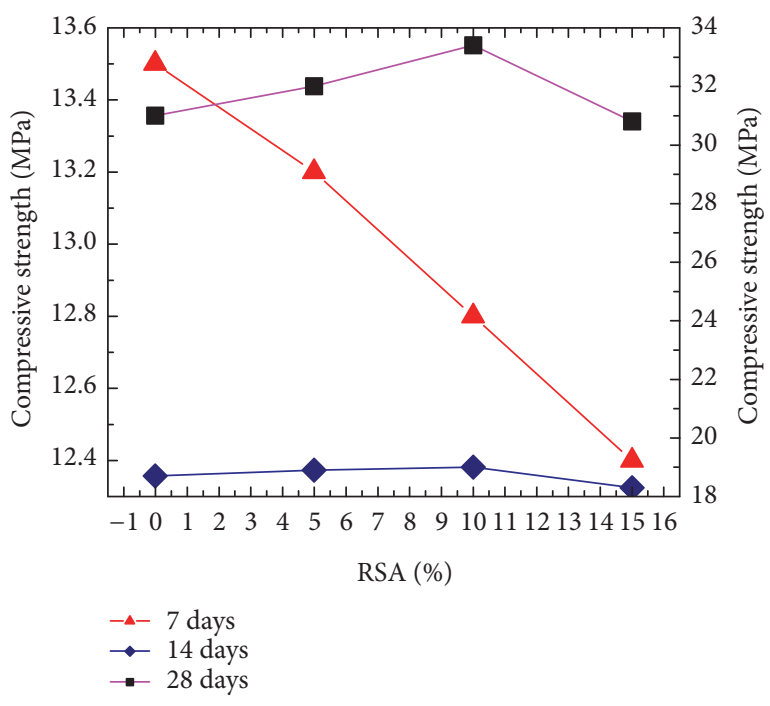

FIGURE 8: Variations of compressive strength.

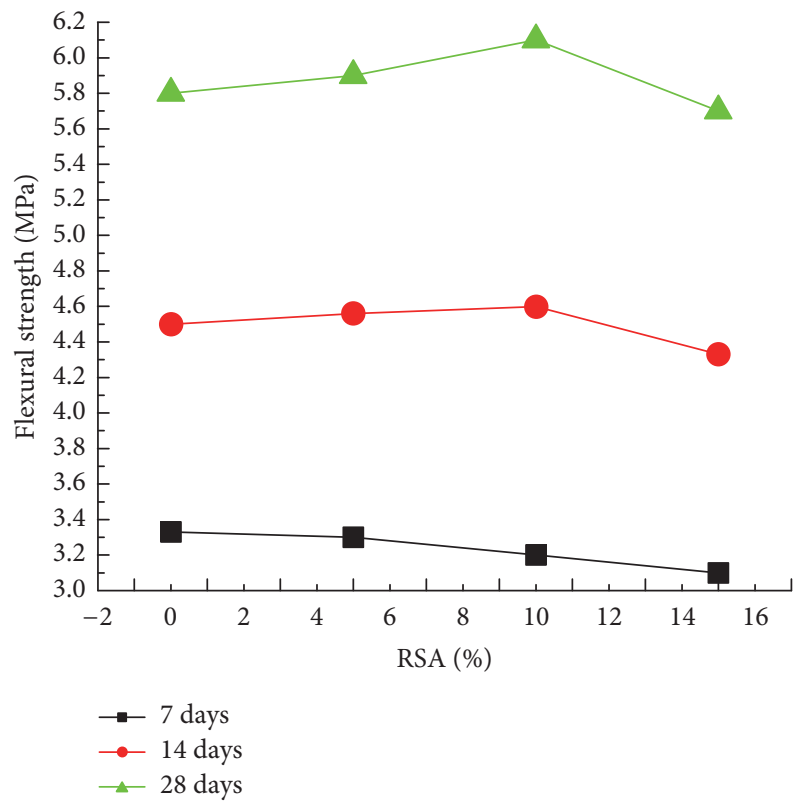

FIGURE 9: Variations of flexural strength.

strength of mortar containing RSA was lower than that of the control mortar OPC at the age of 7 days. However, 5\% and $10 \%$ of cement replacement by RSA gradually increase strength after 14 and 28 days, respectively. It was observed that the strength development increased with age up to a certain percentage of replacement of cement with RSA. The mix $10 \%$ RSA increases about $7 \%$ of its strength after 28 days compared with the controlled specimen. At the 15\% RSA, the compressive strength decreases to a value which is lower than that of control specimen, as the amount of cement $(\mathrm{CaO}$ and $\mathrm{Al}_{2} \mathrm{O}_{3}$ ) is getting low.

3.6. Flexural Strength. The results of variation in flexural strength of mortar incorporated with RSA at the ages of 7, 14, and 28 days are shown in Figure 9. It can be clearly seen that 

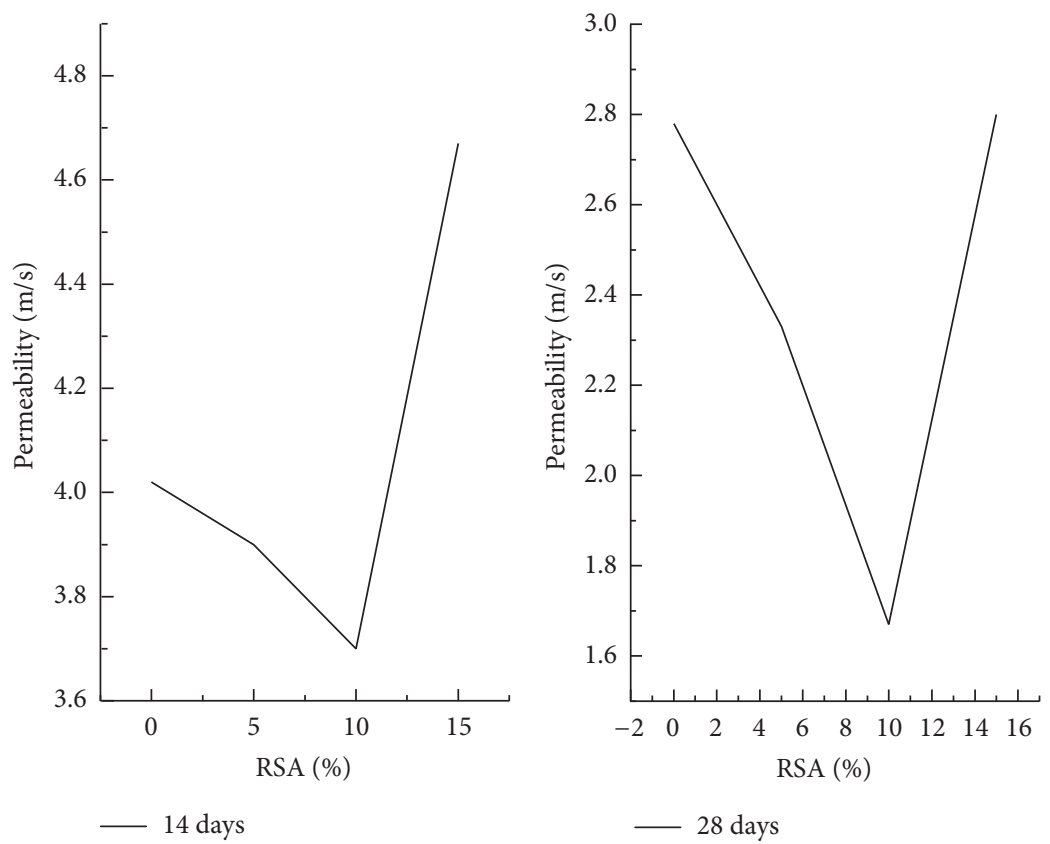

Figure 10: Permeability at 14 and 28 days.

TABLE 4: Variations in workability.

\begin{tabular}{lcccc}
\hline Cement mix with RSA & W/B ratio & Workability $(\mathrm{mm})$ & W/B ratio & Workability $(\mathrm{mm})$ \\
\hline $0 \%$ & 0.5 & 110 & 0.5 & 110 \\
$5 \%$ & 0.5 & 105 & 0.6 & 110 \\
$10 \%$ & 0.5 & 102 & 0.68 & 110 \\
$15 \%$ & 0.5 & 91 & 0.75 & 110 \\
\hline
\end{tabular}

the flexural strength values are almost equivalent to that of OPC beam. But there is certain increase of $10 \%$, whereas $5 \%$ and $10 \%$ of cement replacement by RSA are almost equivalent. For each blend, three beams have been organized. The flexural strength reported in each blend was the average of three beams.

3.7. Water Permeability. The water permeability results at the ages of 14 days and 28 days are shown in Figure 10. The figure is divided into two regions. Region I represents mortar which has both compressive strength and permeability limits at age of 14 days and region II indicates 28 days, respectively. The water permeabilities of OPC sample at 14 and 28 days were $4.02 \times 10^{-12}$ and $2.78 \times 10^{-12} \mathrm{~m} / \mathrm{s}$, respectively. It has been observed that the permeabilities of all specimens reduced with the curing aging. For example, the permeabilities of mortar with $10 \%$ of RSA were $3.7 \times 10^{-12}$ and $1.67 \times 10^{-12} \mathrm{~m} / \mathrm{s}$ at 14 and 28 days, respectively; these are lower than that of OPC sample. These results were affected by the $\mathrm{W} / \mathrm{B}$ ratio as well as the pozzolanic reaction of RSA. However, the use of $5 \%$ and $10 \%$ of RSA to replace Portland cement still produces mortar with lower permeability than the OPC specimen. The increase of RSA in mortar resulted in a higher permeability of mortar since the permeability of mortar with $15 \%$ RSA was higher than that of $10 \%$. At 28 days, the permeability of RSA specimen slightly reduced from the age of 14 days.

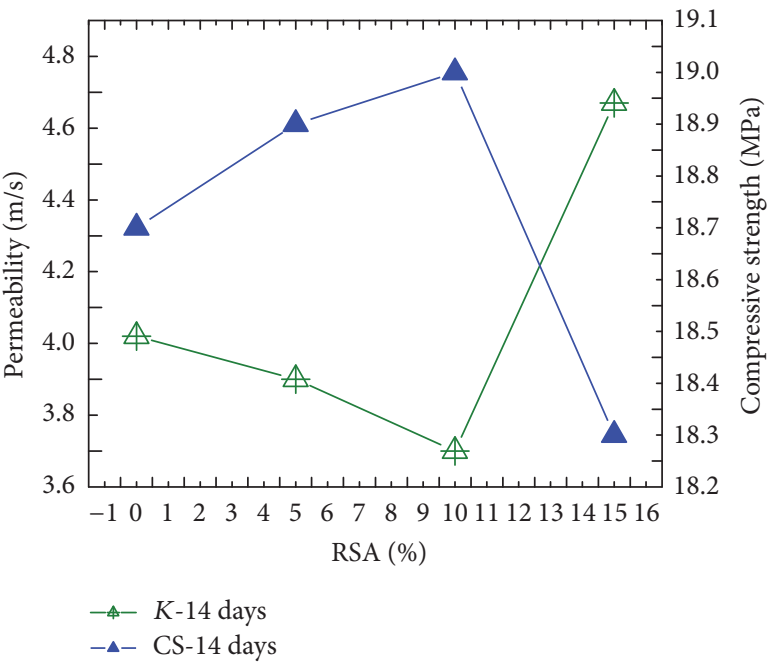

FIGURE 11: Relationship between $K$ and CS at 14 days.

3.8. Relationship between Compressive Strength and Water Permeability. The relationships between the permeability and the compressive strength of mortar cubes at 14 and 28 days are presented in Figures 11 and 12, respectively. It can be seen that at 14 days, the relationship was more scattered 


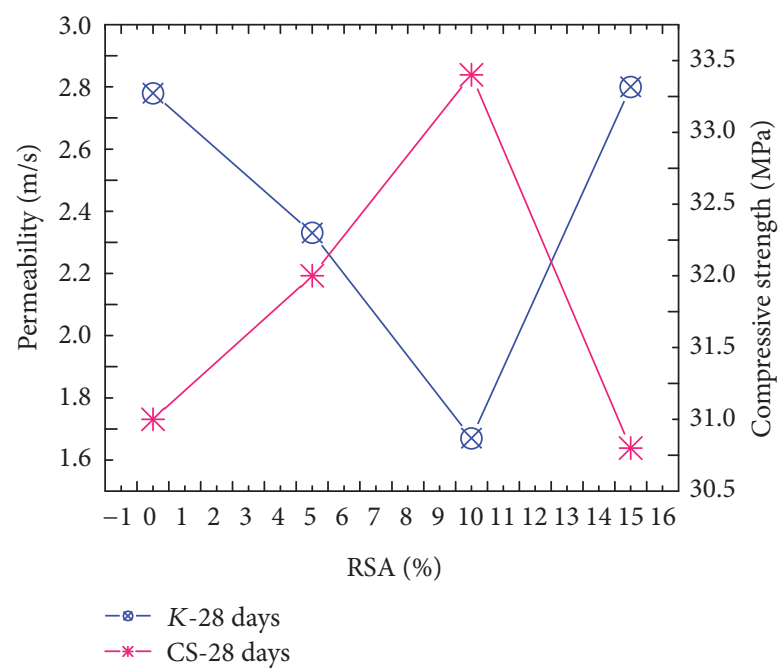

FIGURE 12: Relationship between $K$ and CS at 28 days.

than the relationship at 28 days. The result shows that the permeability decreases with the increasing in the compressive strength. Both figures show that at $15 \%$ replacement of cement by RSA the strength gradually decreases and permeability increases. But at $5 \%$ and $10 \%$, the strength increases and the permeability decrease which is worthy for durability of mortar. This means that $10 \%$ replacement of cement by RSA is the prime limit for the improvement of mortar. The principle reasons for the excellent pozzolanic activity and increase in compressive strength are the amorphous silica and the fine particle size of RSA.

\section{Conclusion}

By studying the result analysis the following conclusion can be conducted:

(i) The strength gradually increases up to $10 \%$ replacement level of cement by RSA, compared to that of controlled specimen, whereas at $15 \%$ there is a slender decrease in strength.

(ii) The permeability of RSA mortar depends on the cement replacement ratios and age of mortar. In general, the permeability reduces with the increasing in the compressive strength and age of mortar.

(iii) The ground rice straw ash generated at $600^{\circ} \mathrm{C}$ is suitable as pozzolanic material and may further show better improvement as the age increases. This shows a good promise to utilize this agrowaste material.

\section{Competing Interests}

The authors declare that there is no conflict of interests regarding the publication of this paper.

\section{Acknowledgments}

The authors would like to acknowledge the laboratory team of National Institute of Technology Agartala, India, and
CSIR-NEIST, Jorhat, India. The principal author would like to express gratefulness for the Ph.D. scholarship sponsored by the Indian Government.

\section{References}

[1] H. Binici, F. Yucegok, O. Aksogan, and H. Kaplan, "Effect of corncob, wheat straw, and plane leaf ashes as mineral admixtures on concrete durability," Journal of Materials in Civil Engineering, vol. 20, no. 7, pp. 478-483, 2008.

[2] D. G. Nair, K. S. Jagadish, and A. Fraaij, "Reactive pozzolanas from rice husk ash: an alternative to cement for rural housing," Cement and Concrete Research, vol. 36, no. 6, pp. 1062-1071, 2006.

[3] H. Chao-Lung, B. L. Anh-Tuan, and C. Chun-Tsun, "Effect of rice husk ash on the strength and durability characteristics of concrete," Construction and Building Materials, vol. 25, no. 9, pp. 3768-3772, 2011.

[4] N. Van Tuan, G. Ye, K. Van Breugel, A. L. A. Fraaij, and D. D. Bui, "The study of using rice husk ash to produce ultra high performance concrete," Construction and Building Materials, vol. 25, no. 4, pp. 2030-2035, 2011.

[5] R. Siddique and M. I. Khan, Supplementary Cementing Materials, Engineering Materials, Springer, 2011.

[6] P. J. Ramadhansyah, A. W. Mahyun, M. Z. M. Salwa et al., "Thermal analysis and pozzolanic index of rice husk ash at different grinding time," Procedia Engineering, vol. 50, pp. 101109, 2012.

[7] P. Chindaprasirt, S. Homwuttiwong, and C. Jaturapitakkul, "Strength and water permeability of concrete containing palm oil fuel ash and rice husk-bark ash," Construction and Building Materials, vol. 21, no. 7, pp. 1492-1499, 2007.

[8] F. F. Ataie and K. A. Riding, "Thermochemical pretreatments for agricultural residue ash production for concrete," Journal of Materials in Civil Engineering, vol. 25, no. 11, pp. 1703-1711, 2013.

[9] C. Sujivorakul, C. Jaturapitakkul, and A. Taotip, "Utilization of fly ash, rice husk ash, and palm oil fuel ash in glass fiberreinforced concrete," Journal of Materials in Civil Engineering, vol. 23, no. 9, pp. 1281-1288, 2011.

[10] W. Tangchirapat and C. Jaturapitakkul, "Strength, drying shrinkage, and water permeability of concrete incorporating ground palm oil fuel ash," Cement and Concrete Composites, vol. 32, no. 10, pp. 767-774, 2010.

[11] N. Van Tuan, G. Ye, K. Van Breugel, and O. Copuroglu, "Hydration and microstructure of ultra high performance concrete incorporating rice husk ash," Cement and Concrete Research, vol. 41, no. 11, pp. 1104-1111, 2011.

[12] H. Biricik, F. Aköz, F. Türker, and I. Berktay, "Resistance to magnesium sulfate and sodium sulfate attack of mortars containing wheat straw ash," Cement and Concrete Research, vol. 30, no. 8, pp. 1189-1197, 2000.

[13] J. Bensted and J. Munn, "A discussion of the paper 'study of pozzolanic properties of wheat straw ash," Cement and Concrete Research, vol. 29, pp. 1507-1508, 1999.

[14] V. Saraswathy and H.-W. Song, "Corrosion performance of rice husk ash blended concrete," Construction and Building Materials, vol. 21, no. 8, pp. 1779-1784, 2007.

[15] N. M. Al-Akhras and B. A. Abu-Alfoul, "Effect of wheat straw ash on mechanical properties of autoclaved mortar," Cement and Concrete Research, vol. 32, no. 6, pp. 859-863, 2002. 
[16] S. Rukzon and P. Chindaprasirt, "Strength and carbonation model of rice husk ash cement mortar with different fineness," Journal of Materials in Civil Engineering, vol. 22, no. 3, pp. 253259, 2010.

[17] M. H. Rashid, M. K. A. Molla, and T. U. Ahmed, "Mortar incorporating rice husk ash: strength and porosity," European Journal of Scientific Research, vol. 40, no. 3, pp. 471-477, 2010.

[18] S. Rukzon, P. Chindaprasirt, and R. Mahachai, "Effect of grinding on chemical and physical properties of rice husk ash," International Journal of Minerals, Metallurgy and Materials, vol. 16, no. 2, pp. 242-247, 2009.

[19] K. K. Moulick, "Prospective use of rice husk ash to produce concrete in India," International Journal of Civil, Environmental, Structural, Construction and Architectural Engineering, vol. 9, no. 3, pp. 324-329, 2015.

[20] R. Zerbino, G. Giaccio, and G. C. Isaia, "Concrete incorporating rice-husk ash without processing," Construction and Building Materials, vol. 25, no. 1, pp. 371-378, 2011.

[21] S. K. Agarwal, "Pozzolanic activity of various siliceous materials," Cement and Concrete Research, vol. 36, no. 9, pp. 1735-1739, 2006.

[22] T. Francisco, J. Paul, and R. A. Lilia, "Compressive strength of concrete blended with calcined rice straw ash," in Proceedings of the 3rd ACF International Conference (ACF/VCA '08), pp. 592597, Ho Chi Minh City, Vietnam, November 2008.

[23] S. Munshi, G. Dey, and R. P. Sharma, "Use of rice straw ash as pozzolanic material in cement mortar," International Journal of Engineering and Technology, vol. 5, no. 5, pp. 603-606, 2013.

[24] F. A. Morsy, S. M. El-Sheikh, and A. Barhoum, "Nano-silica and $\mathrm{SiO}_{2} / \mathrm{CaCO}_{3}$ nanocomposite prepared from semi-burned rice straw ash as modified papermaking fillers," Arabian Journal of Chemistry, 2014.

[25] R. R. Zaky, M. M. Hessien, A. A. El-Midany, M. H. Khedr, E. A. Abdel-Aal, and K. A. El-Barawy, "Preparation of silica nanoparticles from semi-burned rice straw ash," Powder Technology, vol. 185, no. 1, pp. 31-35, 2008. 

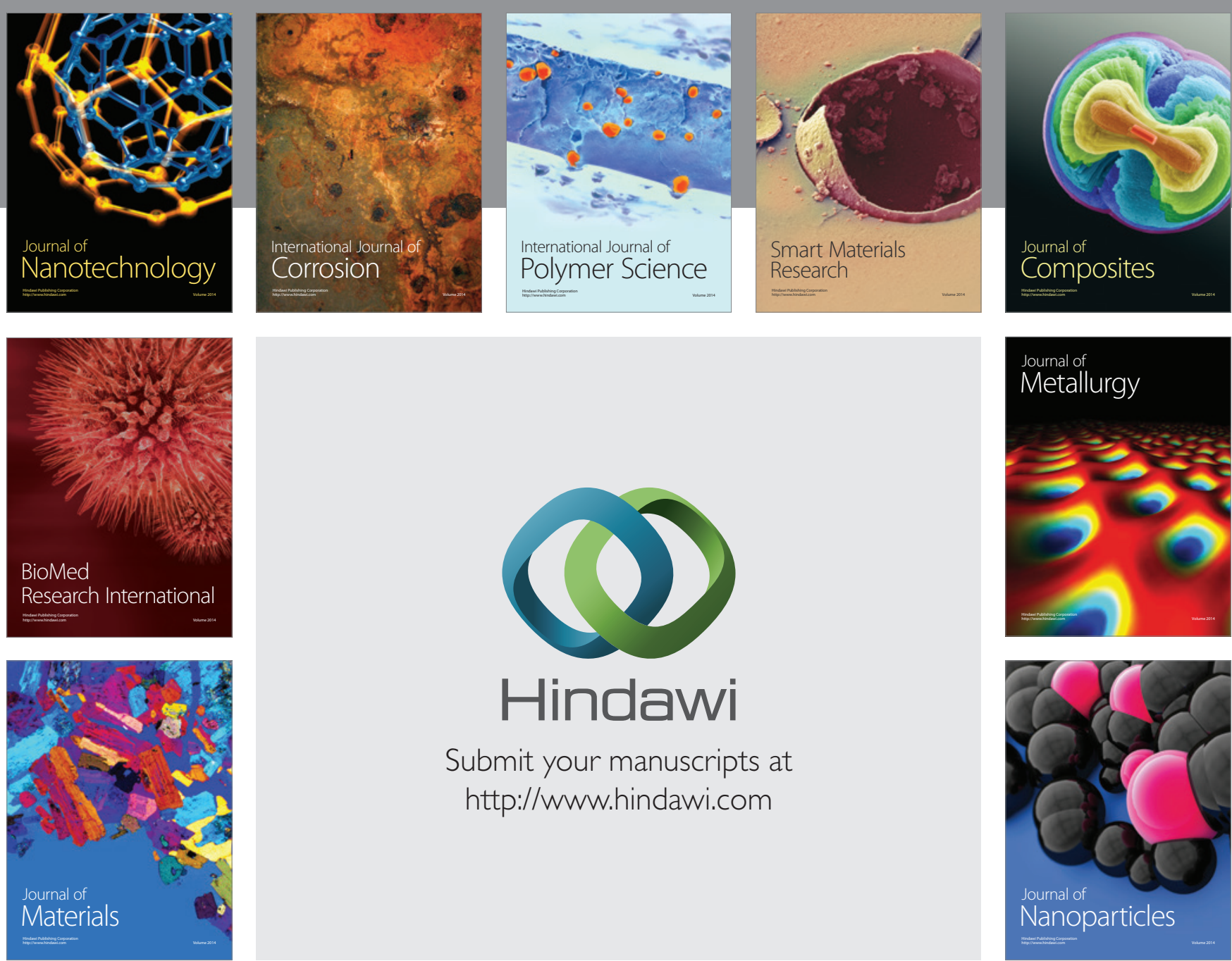

\section{Hindawi}

Submit your manuscripts at

http://www.hindawi.com

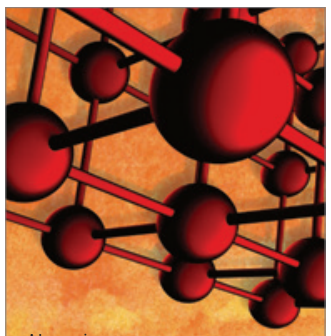

Materials Science and Engineering
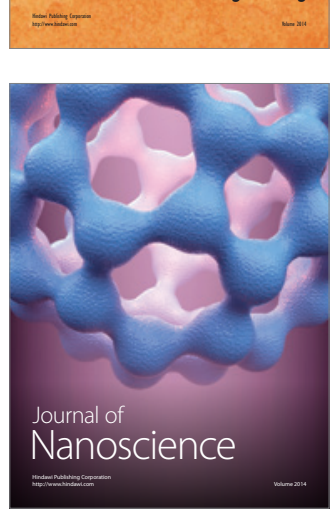
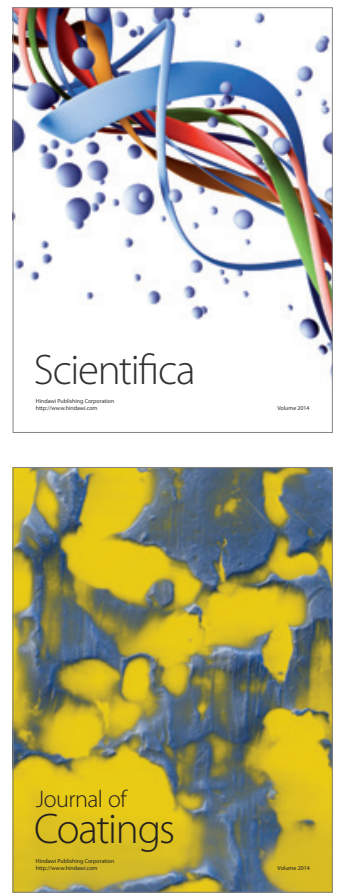
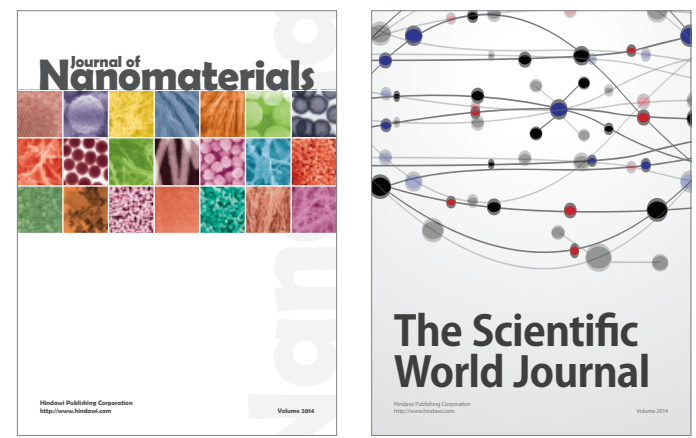

The Scientific World Journal
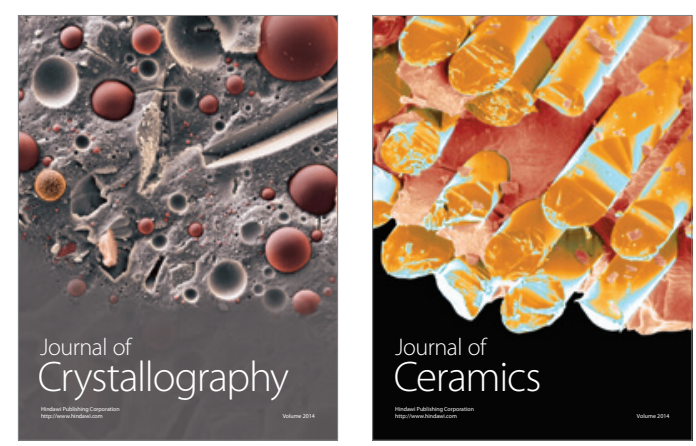
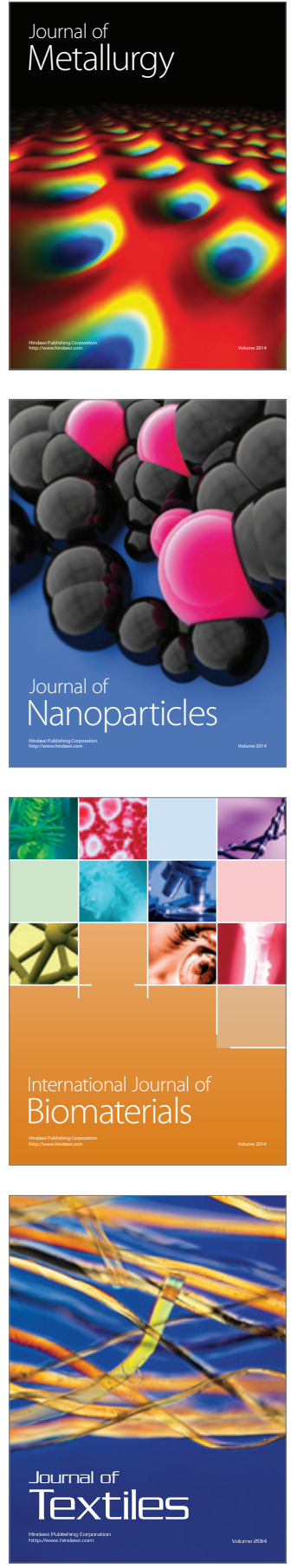